\title{
Effect of floods of different magnitude on the macroinvertebrate communities of Matarranya stream (Ebro river basin, NE Spain)
}

\author{
A. Argerich, M.A. Puig and E. Pupilli \\ Departamento de Biogeoquímica Acuática. Centre d'Estudis Avançats de Blanes, CSIC. Acc. Cala Sant \\ Francesc 14, 17300 Blanes. alba@ceab.csic.es, puig@ceab.csic.es
}

\begin{abstract}
In October 2000, the Matarranya River suffered an extraordinary flood with a measured flow rate of approximately $450 \mathrm{~m}^{3} / \mathrm{s}$ in the town of Vall-de-roures and a return period of about 500 years, according to the Ebro Hydrographic Confederation. The objective of this study was to determine the influence of the consequent perturbation on the structure and composition of the macroinvertebrate community and its subsequent recovery. To this end, two sites in the headwaters of the river, about which information from previous studies was available, were chosen as sampling sites. The Parrissal station, $8 \mathrm{~km}$ from the source with a practically natural flow regime, and at Vall-de-roures, $18 \mathrm{~km}$ from the source and from which part of the flow has been deviated, to be returned in summer from the waters collected in the reservoir on the Pena River. Sampling was carried out one, five and fifteen months after the flood and the data was compared with that obtained before the perturbation, (December, 1998 and February, 1999). On the other hand, we analized the effects of smaller floods occurring in October 1984 (Parrissal) and June 1986 (Vall-de-roures). The results point to different patterns of recovery in the two sampling points after the 2000 flood, the community density recovering more rapidly in the site less affected by anthropic intervention (Parrissal), while the biological quality of the stretch studied in Vall-de-roures involved increased taxonomic richness and greater structuring of the community. The flood events of lesser magnitude did not seem to affect the community structure in Parrissal, while in Vall-deroures the abundance of the predominant groups varied.
\end{abstract}

Keywords: floods, macroinvertebrates, Mediterranean streams, perturbation

\section{RESUMEN}

El río Matarranya padeció en octubre de 2000 una riada extraordinaria, que alcanzó un caudal aproximado de $450 \mathrm{~m}^{3} / \mathrm{s}$ en la población de Vall-de-roures, con un período de retorno estimado de 500 años según la Confederación Hidrográfica del Ebro. El objetivo del presente estudio es determinar la incidencia de esta perturbación sobre la estructura y la composición de la comunidad de macroinvertebrados y su posterior recuperación. Con dicho fin se han muestreado dos estaciones de la cabecera del río de las que se posee información de estudios precedentes. La estación de Parrissal a $8 \mathrm{~km}$ de distancia del nacimiento es una estación con un régimen de caudales prácticamente natural y la estación de Vall-de-roures a $18 \mathrm{~km}$ del nacimiento, esta última ha sufrido la derivación de parte de su caudal, el cual le es retornado durante el periodo estival a través de los aportes del embalse del río Pena. Los muestreos se han realizado un mes, cinco y quince meses después de la riada y se han comparado con los datos obtenidos en dos muestreos previos a dicha perturbación (diciembre de 1998 y febrero de 1999). Por otra parte se han analizado los efectos de crecidas de menor magnitud ocurridas en octubre de 1984 en Parrissal y junio de 1986 en Vall-de-roures. Los resultados nos muestran pautas de recuperación de densidades distintas para las dos estaciones después de la riada de 2000, siendo más rápidas para la estación con un régimen de caudal natural y poca presión antrópica (estación de Parrissal), mientras que los efectos de la riada de mayor magnitud en la estación de Vall-de-roures han comportado una recuperación de la calidad biológica del tramo que ha supuesto un aumento de la riqueza taxonómica y una mayor estructuración de la comunidad. Las riadas de menor magnitud en cambio, parecen no afectar la estructura de la comunidad en Parrissal mientras que en Vall-de-roures se aprecia la variación de las abundancias de los grupos dominantes.

Palabras clave: riadas, macroinvertebrados, ríos mediterráneos, perturbación 


\section{INTRODUCTION}

The hydrological regime is responsible for many of the structural characteristics of rivers, such as current velocity, canal geomorphology and substrate stability. Hence, flow measures can be considered as an integration of environmental conditions (Poff \& Ward, 1989; Poff, 1996). Similarly, variations in the flow of water are frequently related with changes in the community structure of fluvial organisms (Gasith \& Resh, 1999; Gibbins et al., 2001; Thomson, 2002). The rivers of regions with a Mediterranean climate are modeled physically, chemically and biologically by sequential, seasonal and predictable episodes of low and high water levels during the annual cycle (Gasith \& Resh, 1999). As a consequence, aquatic communities follow a hydrological cycle marked by the beginning of the rainy season (Puig et al., 1986; Puig et al., 1990). During most of the year, the macroinvertebrate community of Mediterranean rivers is

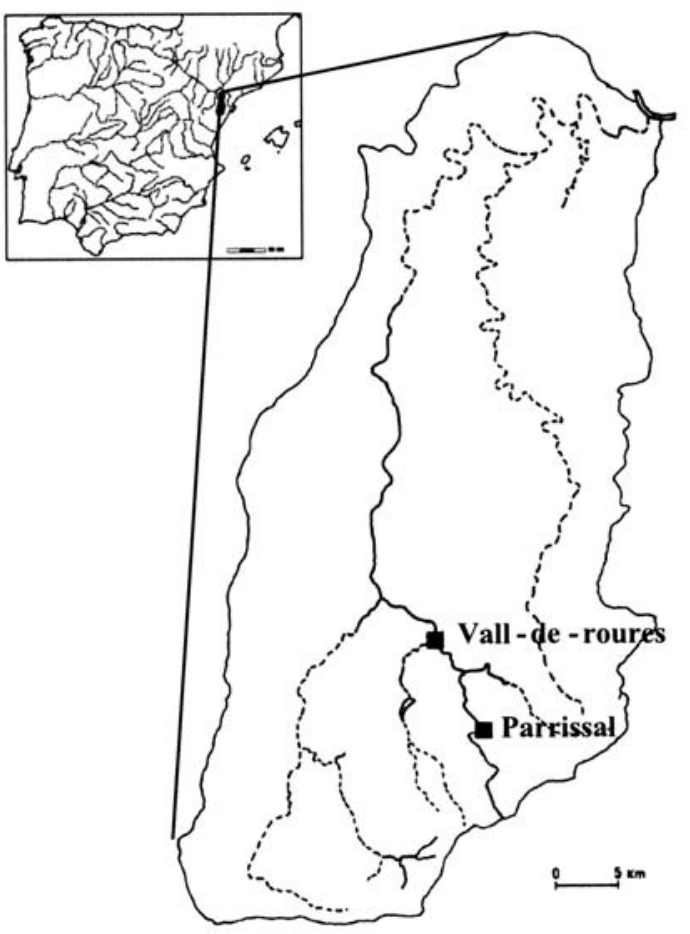

Figure 1. Location of the sampling stations. Localización de las estaciones de muestreo. governed by abiotic factors, especially by the frequency or the intensity of flood waters (Sabater et al., 1995). To this must be added the existence of long drought periods (Prat et al., 1985), which implies greater variability and lower predictability of the aforesaid floods.

On the $20^{\text {th }}$ of October 2000, the headwaters of the Matarranya River suffered an extraordinary flood with an estimated return period of 500 years. This followed three days of heavy rainfall, when $6531 / \mathrm{m}^{2}$ were registered in Mont Caro, $450 \mathrm{l} / \mathrm{m}^{2}$ in Beseit and $356 \mathrm{l} / \mathrm{m}^{2}$ in Vallde-roures. This unusual event has enabled us to study the effects of serious flooding on the macroinvertebrate community and to compare them with the effects of less serious flooding, as recorded in previous years.

\section{STUDY AREA}

The Matarranya is a tributary on the right bank of the river Ebro, in the northeast of the Iberian Peninsula. It rises in Puertos de Tortosa-Beseit 1296 meters a.s.l. and discharges into the Ribarroja reservoir $100 \mathrm{~km}$ downstream.

Two sampling stations, studied at different times since 1984, were selected for this study, Parrissal and Vall-de-roures (Fig. 1). The first is situated $8 \mathrm{~km}$ from the source at an altitude of $650 \mathrm{~m}$. in a protected, forested area of the National Reserve for Hunting. Upstream from the sampling site a small amount of water is extracted to provide drinking water to Beseit. The second sampling site is $18 \mathrm{~km}$ from the source, at an altitude of $508 \mathrm{~m}$., and situated just before the town of Vall-de-roures. At this point, the river has already crossed a populated stretch, and an agricultural and cattle raising zone. Some of its waters have been diverted to the Pena Reservoir on the river Pena and two tributaries have joined it, the Ulldemó from the right and the Pena from the left. The latter returns part of the waters extracted but at a different rate from the natural one, since the reservoir on the same river releases water for irrigation purposes during the summer months. 


\section{MATERIAL AND METHODS}

Sampling took place one month (November 2000), five months (March 2001) and fifteen months (January 2002) after the extraordinary flood that occurred on the $20^{\text {th }}$ of October 2000 . The findings were compared with data taken from previous studies referring to December 1998 and February 1999, and with the findings of samplings made following other much less serious flood events in October and November of 1984 and March of 1985 (Parrissal), and in May and June of 1986 (Vall-de-roures).

In each sampling site the following parameters were measured "in situ": $\mathrm{pH}$ (with an Orion 230A pHmeter), water temperature, dissolved oxygen (Orion 830 oximeter), and conductivity (Orion 105 coductivimeter). Samples were also taken for the laboratory analyses of nitrites, nitrates, silicates and soluble reactive phosphorus (TRAACS-2000 auto-analyser). To estimate the flow-rate at the sampling points, transects were made, in which the depth and velocity of the surface and in-depth current velocity were measured every $50 \mathrm{~cm}$, using a Great Atlantic current-meter (Ohio Professional). Two points were selected at each sampling station to collect macroinvertebrate samples, both in the same section of rapids that were studied in previous years, one in a zone of maximum velocity and another in a more slowly moving zone. At each point, samples were collected using a modified surber of $0.1 \mathrm{~m}^{2}$ surface area with a $250 \mathrm{~mm}$ mesh net. The samples were fixed in the field with $4 \%$ formaldehyde, and separated in the laboratory, where they were identified at the maximum level possible, including the chironomids. At the same time that the macroinvertebrate samples were taken, a series of measurements were made of the microhabitat associated with surbers: substrate composition, algal cover and quantity of organic matter.

As descriptors of the macroinvertebrate community, density (expressed as individuals $/ \mathrm{m}^{2}$ ), taxonomic richness (number of taxa present in the sample) and the specific richness of the groups least tolerant of contamination (Ephemeroptera,
Plecoptera, and Trichoptera) were used as a measurement of the quality of the community by estimating the EPT index (Lenat, 1988).

To understand the high water patterns of the head of the basin, a series of daily flow measurements were consulted, covering a period of twenty years (from 1 October 1980 to 30 September 2000) obtained from the flow assessment stations $\mathrm{n}^{\circ} 52$ (Matarranya river in Beseit town before the confluence of the Ulldemó) and $\mathrm{n}^{\mathrm{o}} 109$ (the Pena stream in Vall-de-roures before its confluence with the Matarranya river) provided by the Hydrographical Confederation of the Ebro (CHE). The data from the first station were used for estimate the flow pattern at the Parrissal sampling station and the combined flows of both stations for the Vall-de-roures sampling point, although the flows obtained may have been slightly lower than the real when little water was contributed from the reservoir. Data for the 81 days (out of 7300) for which no information was available was estimated by lineal interpolation. The hydrological series terminates on September 30,2000 because the flood occurring in October of the same year actually destroyed the flow assessment stations on the Matarranya. The CHE estimates a flow of $450 \mathrm{~m}^{3} / \mathrm{s}$ for Vall-de-roures and although no data are available for Parrissal, the water level reached $3.2 \mathrm{~m}$ above the upper channel limit at our measuring point.

As a definition of "flooding" the suggestion of Garcia-Ruiz et al. (1985) for rivers in Alto Aragón was used, these authors consider floods to be all those flows that exceed five times the mean annual flow.

\section{RESULTS}

\section{Hydrological regime}

The flow regimes of Mediterranean rivers usually reflect rainfall and therefore show a high degree of seasonal and annual variability. In other words, even though the high water levels of spring and autumn may be predictable, their intensity and frequency will vary enor- 


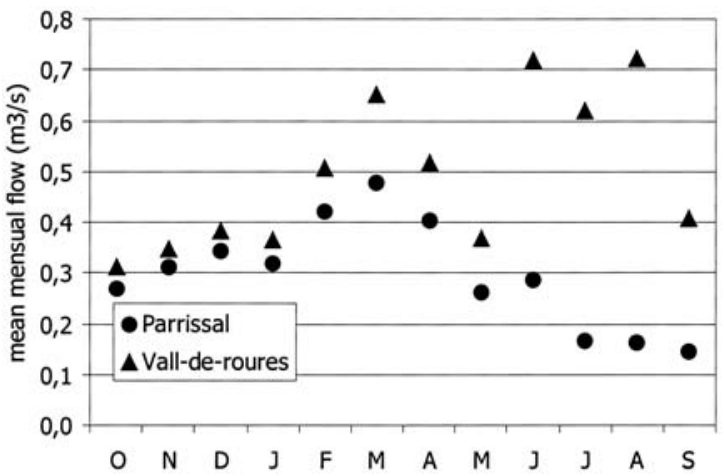

Figure 2. Mean monthly flow rates from the record series covering 20 years for Parrissal and Vall-de-roures. Medias mensuales de caudal a partir de la serie de 20 años hidrológicos para Parrissal y Vall-de-roures.

mously from one year to the next because of changing rainfall patterns.

A study of the data covering twenty years for the Matarranya River points to two different patterns for the sampling stations mentioned

Table 1. Flood data registered in Parrissal from 1980 to 2000. Relación de inundaciones registradas en Parrissal desde 1980 a 2000.

\begin{tabular}{|c|c|c|c|c|c|c|c|c|c|c|c|c|c|}
\hline \multirow{2}{*}{ year } & \multicolumn{13}{|c|}{ month } \\
\hline & o & $\mathrm{n}$ & d & $\mathrm{j}$ & $\mathrm{f}$ & $\mathrm{m}$ & $\mathrm{a}$ & $\mathrm{m}$ & $\mathrm{j}$ & $\mathrm{j}$ & $\mathrm{a}$ & $\mathrm{s}$ & $\Sigma$ \\
\hline $80-81$ & & & & & & & 1 & & & & & & 1 \\
\hline $81-82$ & & & & 1 & 1 & & & & & & & & 2 \\
\hline $82-83$ & 1 & & & & & & & & & & & & 1 \\
\hline $83-84$ & & 1 & & & & & & & & & & & 1 \\
\hline $84-85$ & & & & & & & & & & & & & 0 \\
\hline $85-86$ & & & & & & & & & & & & & 0 \\
\hline $86-87$ & 1 & & & 1 & & & & & & & & & 2 \\
\hline $87-88$ & 1 & & & 1 & & & 1 & & & & & & 3 \\
\hline $88-89$ & 1 & 1 & & & & 1 & & 1 & & & & & 4 \\
\hline $89-90$ & & & 1 & & & & & & & & & & 1 \\
\hline $90-91$ & 1 & & & & 2 & 1 & 1 & & & & & & 5 \\
\hline $91-92$ & & & 1 & & & & & 2 & & 1 & & & 4 \\
\hline $92-93$ & & & 1 & & 1 & 1 & & & & & & & 3 \\
\hline $93-94$ & & & & & & & & & & & & & 0 \\
\hline $94-95$ & 1 & & & & & & & & & & & & 1 \\
\hline $95-96$ & & & 1 & & & & & & & & & & 1 \\
\hline $96-97$ & & & 1 & & & & & & & & & & 1 \\
\hline $97-98$ & & & & 1 & & & & & & & & & 1 \\
\hline $98-99$ & & & & & & & & & & 1 & & & 1 \\
\hline 99-00 & & & & & & & & & 1 & & & & 1 \\
\hline$\Sigma$ & 6 & 2 & 5 & 4 & 4 & 3 & 3 & 3 & 1 & 2 & 0 & 0 & 33 \\
\hline
\end{tabular}

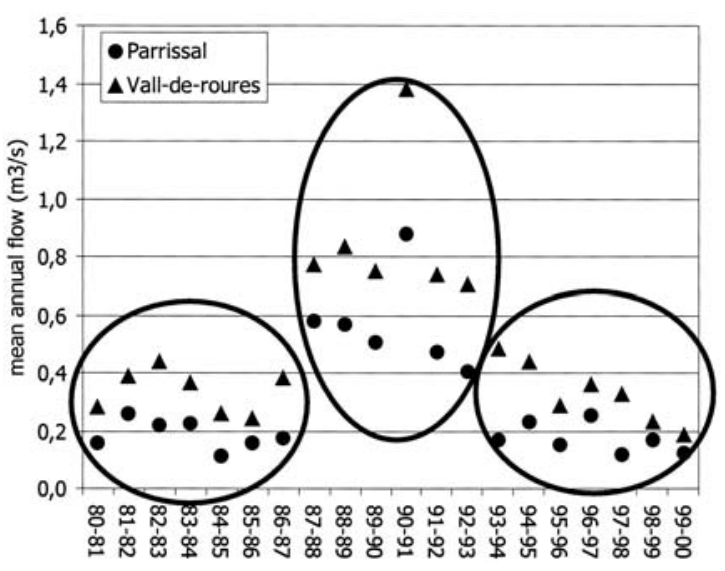

Figure 3. Mean annual flow for the two sampling stations (1980-2002). Medias anuales de caudal para las dos estaciones de muestreo (1980-2002).

Table 2. Flood data registered in Vall-de-roures from 1980 to 2000 In italics the floods registered during the reservoir influence period. Relación de inundaciones registradas en Vall-de-roures desde 1980 a 2000. La cursiva indica los picos de caudal registrados durante el periodo de influencia del embalse.

\begin{tabular}{|c|c|c|c|c|c|c|c|c|c|c|c|c|c|}
\hline \multirow{2}{*}{ year } & \multicolumn{13}{|c|}{ month } \\
\hline & o & $\mathrm{n}$ & $\mathrm{d}$ & $\mathrm{j}$ & f & $\mathrm{m}$ & $\mathrm{a}$ & $\mathrm{m}$ & $\mathrm{j}$ & $\mathrm{j}$ & $\mathrm{a}$ & $\mathrm{s}$ & $\Sigma$ \\
\hline $80-81$ & & & & & & & 1 & & 1 & 1 & 1 & & 4 \\
\hline $81-82$ & & & & & & & & & 1 & 1 & 1 & & 3 \\
\hline $82-83$ & 1 & & & & & & 1 & 1 & & 1 & 1 & & 5 \\
\hline $83-84$ & & 1 & & & & & & & & 2 & & 1 & 4 \\
\hline $84-85$ & & & & & & & & & & 1 & 1 & & 2 \\
\hline $85-86$ & & & & & & & & & 1 & & & & 1 \\
\hline $86-87$ & & & & & & & & & 1 & & 1 & 1 & 3 \\
\hline $87-88$ & & & & 1 & & & 1 & & & & 1 & 1 & 4 \\
\hline 88-89 & 1 & 1 & & & & 1 & & & 1 & 1 & 1 & & 6 \\
\hline $89-90$ & & & 1 & & & & & 1 & & 1 & 1 & 1 & 5 \\
\hline $90-91$ & 1 & & & & 2 & 2 & 1 & & & 1 & 1 & & 8 \\
\hline $91-92$ & & & & & & & & 2 & & & & & 2 \\
\hline $92-93$ & & & 1 & & 1 & & & & 1 & 1 & 1 & 1 & 6 \\
\hline $93-94$ & & & & & & & & & 2 & 1 & 1 & 1 & 5 \\
\hline $94-95$ & 1 & & & & & & & & 2 & & 1 & & 4 \\
\hline $95-96$ & & & & & & & & & & 1 & 1 & & 2 \\
\hline $96-97$ & & & & & & & & & & 1 & 1 & & 2 \\
\hline $97-98$ & & & & & & & & & 1 & & & & 1 \\
\hline $98-99$ & & & & & & & & & & & 1 & & 1 \\
\hline 99-00 & & & & & & & & & 1 & & 1 & & 2 \\
\hline$\Sigma$ & 4 & 2 & 2 & 1 & 3 & 3 & 4 & 4 & 12 & 13 & 16 & 6 & 70 \\
\hline
\end{tabular}


(Fig. 2). On the one hand, Parrissal has a typically Mediterranean flow regime, in which four periods can be distinguished: from October to January, a period of intermediate flows; from February to April, a period of high flows; May and June, intermediate levels and, finally, from July to September, very low flows. Vall-de-roures, on the other hand, shows a reverse pattern, with minimum flows in winter and maximum in summer due to the regulating effect of the Pena reservoir. Here, the pattern can be divided into a more or less natural period (from October to May) and a second period when the flow is determined by the contributions made by the above mentioned reservoir (June to September).

During the twenty year period studied, two drought periods can be distinguished, one from October 1980 to September 1987, and the other from October 1993 to September 2000, as well as one wet period running from October 1987 to September 1989. All the flood events studied for this project occurred either during dry periods or mark the end of one (for example, the flood of October 2000). The maximum average flow for both stations occurred in the hydrological year 1990-91 (Fig. 3).

Using the above-mentioned criterion, we considered floods all whose flow exceeded $1.473 \mathrm{~m}^{3} / \mathrm{s}$ in Parrissal and $2.451 \mathrm{~m}^{3} / \mathrm{s}$ in Vall-deroures. Peaks occurring within four days of the same flood period are considered to belong to the same event. As Table 1 shows, the floods in
Parrissal occurred mainly in October, while the fewest events coincided with the low summer flow periods. At this sampling point, most floods occurred in the wet years between 1987 and 1993. In Vall-de-roures, the months when the highest number of floods occurred were those during which the Pena reservoir released water for irrigation purposes (Table 2). The frequency with which the floods occurred was 1.65 per year in Parrissal and 3.5 per year in Vall-de-roures, although if the calculations are made referring to the natural flow regime in Vall-de-roures, the more upstream site (Parrissal) has more frequent floods due to the cushioning effect caused by the transfer of water to the Pena River.

\section{Physical and -chemical, and morphometric data}

The different physical and chemical parameters recorded during the samplings made before and after the flood of 2000 are summarized in Table 3 . The greater concentration of nitrates in Vallde-roures is probably the result of agricultural and cattle raising activity in the area. The dilution effect of the flood led to a decrease in the concentration of these compounds in both sampling sites. Conductivity, phosphate levels, and nitrites, on the other hand, varied very little. Winter water temperatures, especially in Parrissal, were moderate (never falling below $9^{\circ} \mathrm{C}$ ), as observed in previous studies (Malo, 1993).

Table 3. Physical and chemical characteristics recorded at the two sampling stations for the 1998-99 and 2000-2002 sampling periods. Características fisicoquímicas de las dos estaciones de muestreo para los muestreos de 1998-99 y 2000-2002.

\begin{tabular}{|c|c|c|c|c|c|c|c|c|}
\hline & & $\begin{array}{c}\text { PRS } \\
(\mu \mathrm{mol} / \mathrm{l})\end{array}$ & $\begin{array}{l}\text { Nitrate } \\
(\mu \mathrm{mol} / \mathrm{l})\end{array}$ & $\begin{array}{c}\text { Nitrite } \\
(\mu \mathrm{mol} / \mathrm{l})\end{array}$ & $\begin{array}{c}\text { Cond } \\
(\mu S)\end{array}$ & $\mathbf{p H}$ & $\begin{array}{c}\mathrm{O}_{2} \\
(\mathrm{mg} / \mathrm{l})\end{array}$ & $\begin{array}{c}\text { Temp } \\
\left({ }^{\circ} \mathrm{C}\right)\end{array}$ \\
\hline \multirow[t]{5}{*}{ Parrissal } & $\operatorname{dec} 98$ & 0.0953 & 15.5539 & 0.0000 & 419 & 8.74 & 5.08 & 9.8 \\
\hline & feb99 & 1.3606 & 12.4676 & 0.1364 & 475 & 9.30 & 6.20 & 10.2 \\
\hline & nov00 & 0.3800 & 9.7300 & 0.0000 & 430 & 9.20 & 6.75 & 10.9 \\
\hline & $\operatorname{mar} 01$ & 0.2092 & 13.6444 & 0.0736 & 437 & 8.83 & 4.52 & 12.3 \\
\hline & jan02 & 4.2800 & 22.5600 & 0.2730 & 462 & 8.44 & 10.51 & 9.3 \\
\hline \multirow[t]{5}{*}{ Vall-de-roures } & dec98 & 0.7310 & 79.8411 & 0.1781 & 423 & 8.92 & 6.06 & 10.1 \\
\hline & feb99 & 0.9831 & 45.6180 & 0.5263 & 434 & 9.29 & 7.49 & 7.2 \\
\hline & nov00 & 0.4600 & 14.0800 & 0.0700 & 421 & 9.24 & 7.69 & 11.7 \\
\hline & $\operatorname{mar} 01$ & 0.4659 & 45.0990 & 0.1766 & 416 & 8.31 & 4.58 & 16.2 \\
\hline & jan02 & 0.4200 & 44.4300 & 0.1810 & 386 & 8.62 & 14.55 & 10.0 \\
\hline
\end{tabular}


Argerich et al.

Table 4. Changes in the riverbed at the two sampling stations for the 1998-99 and 2000-2002 sampling periods. Evolución del lecho del río en las dos estaciones de muestreo para los muestreos de 1998-99 y 2000-2002.

\begin{tabular}{|c|c|c|c|c|c|c|c|c|c|c|}
\hline & \multicolumn{5}{|c|}{ Parrissal } & \multicolumn{5}{|c|}{ Vall-de-roures } \\
\hline & dec-98 & feb-99 & nov-00 & mar-01 & jan-02 & dec-98 & feb-99 & nov-00 & $\operatorname{mar}-01 \mathbf{j}$ & jan-02 \\
\hline streamflow $\left(\mathrm{m}^{3} / \mathrm{s}\right)$ & 0.027 & 0.020 & 00.156 & 0.134 & 0.062 & 0.261 & 0.150 & 0.997 & 0.433 & 0.103 \\
\hline inundated area $\left(\mathrm{m}^{2}\right)$ & 0.320 & 0.665 & $5 \quad 1.315$ & 1.454 & 0.313 & 1.148 & 1.001 & 2.370 & 1.620 & 1.018 \\
\hline medium depth $(\mathrm{cm})$ & 5.82 & 13.78 & 17.86 & 18.17 & 9.21 & 16.39 & 18.27 & 26.33 & 19.06 & 20.35 \\
\hline medium depth velocity $(\mathrm{m} / \mathrm{s})$ & 0.09 & 0.08 & 0.10 & 0.08 & 0.11 & 0.16 & 0.12 & 0.22 & 0.22 & 0.07 \\
\hline algal cover $(\%)$ & 96.0 & 76.0 & $<1.0$ & 28.5 & 71.0 & 76.5 & 79.0 & 27.5 & 22.5 & 78.0 \\
\hline organic matter (dry weight) (g) & 11.76 & 3.09 & 0.23 & 2.48 & 5.88 & 3.88 & 0.31 & 2.04 & 3.00 & 3.96 \\
\hline
\end{tabular}

The flood of 2000 changed the riverbed at Parrissal and, whereas previously a sand bar with vegetation separated the river into two channels, only one, wider and deeper channel remained afterwards (Table 4). In Vall-de-roures, the flood changed the area of rapids and pools so that what was previously a rapid is now a pool and viceversa. This means that the new rapids that formed upstream of the previous ones are now considered as a new study site since it is nearer the zone studied in previous samplings. In general, the wetted zone of the river channel became wider although by January of 2002 the channel had become narrower and deeper (Table 4).

The effects of the flood were also apparent in the changes seen in the substrate (Fig. 4). In Parrissal, cobbles dominate the post flood substrate and, since all the smaller material has been

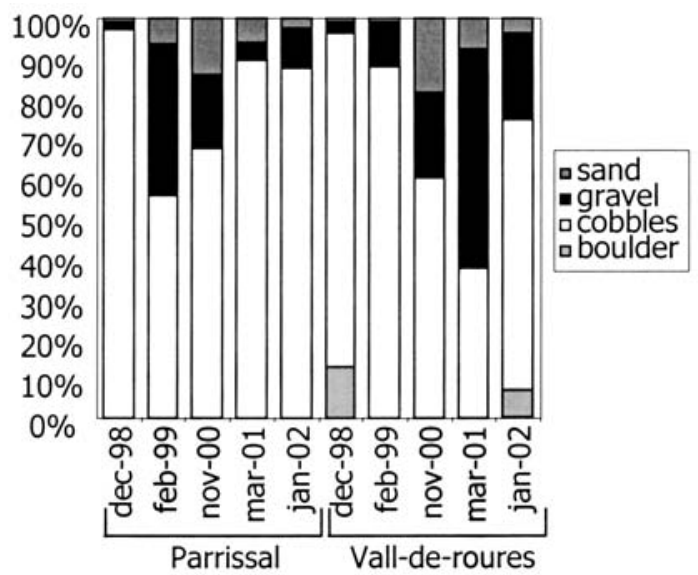

Figure 4. Changes in substrate composition (1998-2002). Evolución de la composición del substrato (1998-2002). washed away, this situation continued at the next sampling period. In Vall-de-roures, on the other hand, fine material (sand and gravel) had accumulated, brought downstream from the upstream drainage watershed. This situation was more evident in March, 2001 as a result of the gravels from the repair works being carried out after the flood or due to the irregular extraction of mineral aggregates upstream of the sampling point.

\section{Macroinvertebrate community structure in Parrissal}

The communities present in December 1998 and February 1999 were considered as reference communities for comparing the data obtained after the flood of October 2000 in the samplings of November of 2000, March of 2001 and January of 2002. To study the changes in the macroinvertebrate community of Parrissal following the minor flood, which occurred at the beginning of November 1984 (maximum of $2.5 \mathrm{~m}^{3} / \mathrm{s}$, according to the $\mathrm{CHE}$ ), we used the samples taken in October and November of that year, and March of 1985.

Density: The 1984 flood led to a loss of $75.2 \%$ in the community density, while the loss caused by the 2000 flood was $97.6 \%$. Recovery patterns were similar in both cases, five months after the minor flood the density recovered to $59.6 \%$ and to $62.1 \%$ in March 2001.

Dominant groups: As can be observed from Table 5, mayflies, stoneflies, caddisflies, and beetles increased in proportion after the 1984 
Table 5. Density (individuals $/ \mathrm{m}^{2}$ ) of each taxonomic group at Parrissal and EPT index. Densidades (individuos $/ \mathrm{m}^{2}$ ) de cada gran grupo taxonómico en Parrissal e índice EPT.

\begin{tabular}{|c|c|c|c|c|c|c|c|c|}
\hline & oct-84 & nov-84 & mar-85 & dec-98 & feb-99 & nov-00 & mar-01 & jan-02 \\
\hline \multirow[t]{2}{*}{ Ephemeroptera } & 207 & 90 & 270 & 2072 & 3984 & 155 & 1565 & 3865 \\
\hline & $8.4 \%$ & $14.8 \%$ & $27.2 \%$ & $14.1 \%$ & $26.9 \%$ & $43.7 \%$ & $28.0 \%$ & $32.5 \%$ \\
\hline \multirow[t]{2}{*}{ Plecoptera } & 55 & 30 & 70 & 448 & 304 & 70 & 2440 & 1179 \\
\hline & $2.2 \%$ & $4.9 \%$ & $7.0 \%$ & $3.0 \%$ & $2.1 \%$ & $19.7 \%$ & $43.7 \%$ & $9.9 \%$ \\
\hline \multirow[t]{2}{*}{ Odonata } & 60 & 0 & $\mathbf{0}$ & 88 & $\mathbf{0}$ & 0 & 0 & 146.5 \\
\hline & $2.4 \%$ & $0.0 \%$ & $0.0 \%$ & $0.6 \%$ & $0.0 \%$ & $0.0 \%$ & $0.0 \%$ & $1.2 \%$ \\
\hline \multirow[t]{2}{*}{ Trichoptera } & 535 & 140 & 302 & 3056 & 2216 & 15 & 70 & 2727.5 \\
\hline & $21.8 \%$ & $23.0 \%$ & $30.4 \%$ & $20.8 \%$ & $15.0 \%$ & $4.2 \%$ & $1.3 \%$ & $22.9 \%$ \\
\hline \multirow[t]{2}{*}{ Coleoptera } & 100 & 80 & 60 & 424 & 1584 & 35 & 25 & 796 \\
\hline & $4.1 \%$ & $13.1 \%$ & $6.0 \%$ & $2.9 \%$ & $10.7 \%$ & $9.9 \%$ & $0.4 \%$ & $6.7 \%$ \\
\hline \multirow[t]{2}{*}{ Chironomidae } & 1110 & 90 & 153 & 3640 & 3312 & 30 & 1305 & 1648 \\
\hline & $45.2 \%$ & $14.8 \%$ & $15.4 \%$ & $24.8 \%$ & $22.4 \%$ & $8.5 \%$ & $23.4 \%$ & $13.9 \%$ \\
\hline \multirow[t]{2}{*}{ Other Diptera } & 110 & 90 & 50 & 3832 & 1720 & 20 & 35 & 550.5 \\
\hline & $4.5 \%$ & $14.8 \%$ & $5.0 \%$ & $26.1 \%$ & $11.6 \%$ & $5.6 \%$ & $0.6 \%$ & $4.6 \%$ \\
\hline \multirow[t]{2}{*}{ Oligochaeta } & $\mathbf{0}$ & 0 & 18 & 200 & 48 & $\mathbf{0}$ & 100 & 32.5 \\
\hline & $0.0 \%$ & $0.0 \%$ & $1.8 \%$ & $1.4 \%$ & $0.3 \%$ & $0.0 \%$ & $1.8 \%$ & $0.3 \%$ \\
\hline \multirow[t]{2}{*}{ Mollusca } & 120 & 70 & 20 & 176 & 376 & $\mathbf{0}$ & 20 & 20.5 \\
\hline & $4.9 \%$ & $11.5 \%$ & $2.0 \%$ & $1.2 \%$ & $2.5 \%$ & $0.0 \%$ & $0.4 \%$ & $0.2 \%$ \\
\hline \multirow[t]{2}{*}{ Others } & 160 & 20 & $\mathbf{5 0}$ & 768 & 1272 & 30 & 20 & 922.5 \\
\hline & $6.5 \%$ & $3.3 \%$ & $5.0 \%$ & $5.2 \%$ & $8.6 \%$ & $8.5 \%$ & $0.4 \%$ & $7.8 \%$ \\
\hline TOTAL & 2457 & 610 & 993 & 14704 & 14816 & 355 & 5580 & 11888 \\
\hline TOTAL TAXA & 37 & 25 & 27 & 58 & 55 & 18 & 34 & $\mathbf{5 7}$ \\
\hline EPT & 20 & 14 & 15 & 21 & 21 & 10 & 11 & 27 \\
\hline
\end{tabular}

flood, while the chironomids decreased from $45 \%$ to $15 \%$ of the total. The 2000 flood affected the mayflies and stoneflies in the same way but the caddisflies and the Diptera as a whole, proportionally, suffered a decrease.

Community structure: A graphic comparison of the structure of the communities present at the different sampling dates using K-dominance curves (Woodward et al., 2002) is shown in figures 5 and 6 . In these graphs the $\mathrm{Y}$ axis represents the accumulated relative abundance of each species or taxa as a percentage, while the $\mathrm{X}$ axis represents the different species/taxa from greater to smaller abundance. The slope of the curves shows the degree of community structure, so that steeply sloping curves reflect communities dominated by few species, while gentler slopes represent more structured communities (ODPM, 2002, p. 81).

In Parrissal, the 1984 flood had a much smaller effect on the community structure (Fig. 5a) than the one in 2000 (Fig. 5b). Following the first mentioned flood, the number of taxa (Table 5) fell from 37 to 25 in November 1984 and 27 in March 1985. Specific composition also varied, only 16 taxa remained in November of 1984, while in March there were 12, ten of which were present before the flood (Baetis gadeai, Baetis rhodani, Habroleptoides confusa, Perla marginata, Hydroptila martini, Oxyethira cf. frici, Hydropsyche instabilis, Elmis mangetii, Ancylus fluviatilis, hidracari)

The flood in October of 2000 had a destructive effect on the community structure (Fig. 5b). The greatest disorganization was observed in March 2001, although by January 2002 the structure of the community had almost completely recovered.

Taxa richness and EPT index: The number of taxa (Table 5) passed from 58 and 55 in December 1998 and February 1999, respectively, to 18 one month after the flood, 34 in March 2001 and 57 in January 2002. The only species which 

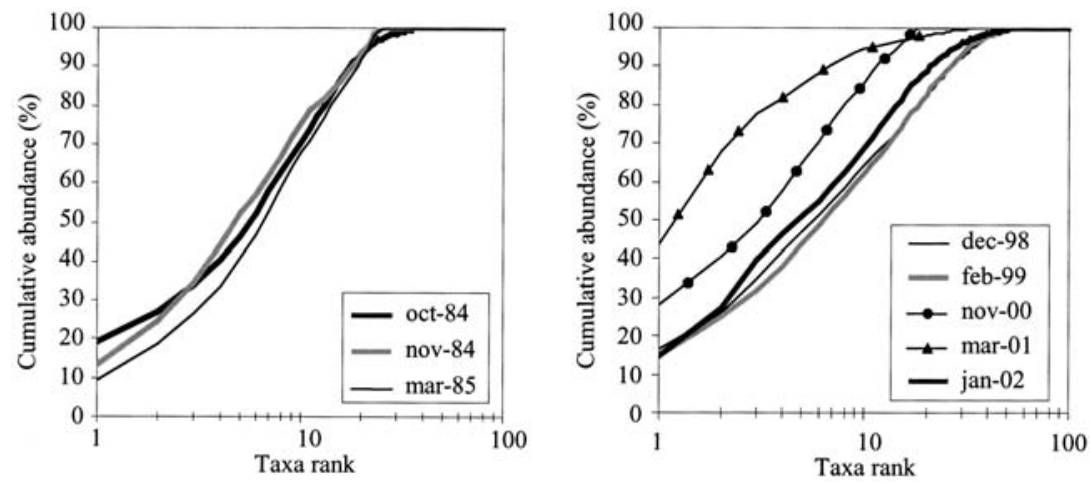

Figure 5. K-dominance curves for Parrissal before and after the 1984 (a) and 2000 (b) floods. Curvas de K-dominancia para Parrissal antes y después de las riadas de 1984 (a) y del 2000 (b).

remained throughout this last sampling series (1998-2000) were Electrogena lateralis, Alainittes muticus, Baetis rhodani, Habroleptoides confusa, Bezzia sp. and Dugesia sp. The values of the EPT index also clearly reflect the great disruption caused by this flood, falling by $50 \%$ (Table $5)$. At the same time, the continued high water levels (well above those measured during the preceding dry periods) favored a considerable rise in this index compared with the winter control conditions considered (February 1999).

\section{Macroinvertebrate community structure in Vall-de-roures}

As in Parrissal, we used the data from December of 1998 and February of 1999 as reference data to evaluate the effects of the 2000 flood $\left(450 \mathrm{~m}^{3} / \mathrm{s}\right)$, comparing them with the data obtained in November of 2000, March, 2001 and January, 2002. On the other hand, we used the data from the samplings carried out in May and July of 1986 to study the effect of the flood occurring in June of the same year, which showed a maximum flow of $10.51 \mathrm{~m}^{3} / \mathrm{s}$, according to the CHE.

Density: The flood of June, 1986 led to a $67.6 \%$ loss of community density, while the flood in 2000 led to a loss of $99.7 \%$. The recovery period can only be studied for this last flood since no details are available for how the community changed after the earlier flood. Community density recovered very slowly after the 2000 flood and in March of 2001 only
$14.8 \%$ of the original density was recorded, rising to $16.9 \%$ in January of 2002 .

Dominant groups: Chironomidae and Trichoptera were the most abundant groups before and after the 1986 flood (Table 6) representing the $56.8 \%$ of the community before the event and increasing to $73 \%$ after the flood. The dominant groups present before the 2000 flood were mayflies, mollusca and chironomids, representing 78\% of the community. After this flood, the proportion of mayflies decreased and caddisflies increased differing from the pattern observed in Parrissal.

Community estructure: In Vall-de-roures the flood of June 1986 caused a certain degree of destructuring (Fig. 6a) since, although the number of taxa remained constant before and after the flood (Table 6), the specific composition varied slightly, seven of the 30 taxa present after the flood being different. However, the main change observed was concerning the relative abundance of the different taxa: in May 1986 the 30 taxa had a relative abundance between 19.97\% (Psychomia pusilla) and $0.03 \%$ (Einfeldia sp.), in July 1986 the figures ranged from the $29.0 \%$ of Psychomia pusilla to the $0.05 \%$ of Psectrocladius sp. The effects of the 2000 flood were clearly more pronounced (Fig. 6b). The flood led to a fall in community organization, which was more pronounced in March (five months later) than it was one month after the flood in November. In January 2002 the community appeared more highly structured than during previous samplings. In December $1998,75 \%$ of the indivi- 

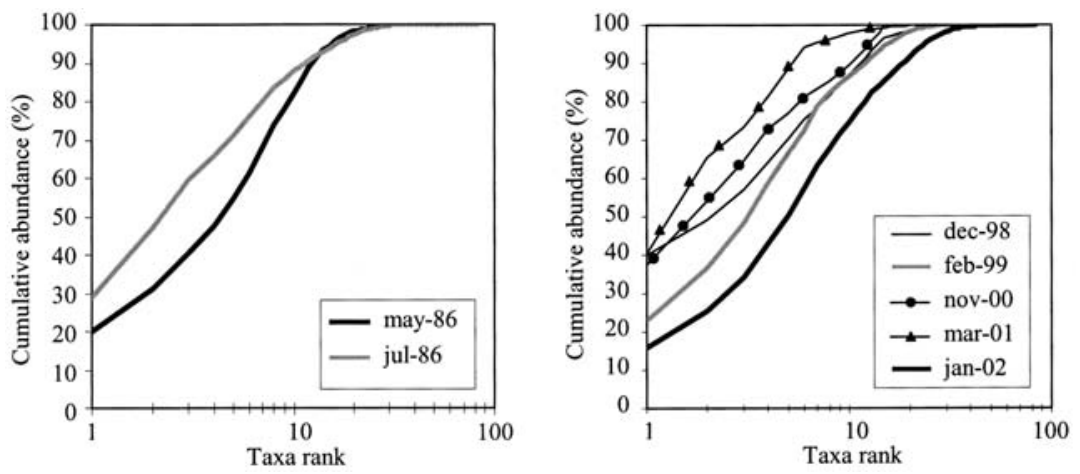

Figure 6. Curvas de K-dominancia para Vall-de-roures antes y después de las riadas de 1986 (a) y del 2000 (b). K-dominance curves for Vall-de-roures before and after the 1986 (a) and 2000 (b) floods.

duals belonged to six species and in February 1999 to seven. After the flood, in November of 2000 , the community was dominated by few taxa, $75 \%$ of the individuals belonging to 5 species. In March, 2001 this figure was 3 species, rising to 11 species in January, 2002.

Taxa richness and EPT index: The number of taxa present in the community also changed after the extraordinary flood, from the 42 registered in the reference samples to 17 in November 2000, 34 in March 2001 and 62 in January 2002. The quality of the community improved up to the point that the EPT index showed values within the higher ranges of those observed in the less disturbed sampling station at Parrissal (Table 6).

Table 6. Density (individuals $/ \mathrm{m}^{2}$ ) of each taxonomic group at Vall-de-roures and EPT index. Densidades (individuos $/ \mathrm{m}^{2}$ ) de cada gran grupo taxonómico en Vall-de-roures e índice EPT.

\begin{tabular}{|c|c|c|c|c|c|c|c|}
\hline & may-86 & jul-86 & dec-98 & feb-99 & nov-00 & mar-01 & jan-02 \\
\hline \multirow[t]{2}{*}{ Ephemeroptera } & 1003 & 217 & 10512 & 9952 & 5 & 230 & 3338.5 \\
\hline & $9.9 \%$ & $3.2 \%$ & $9.7 \%$ & $11.6 \%$ & $2.1 \%$ & $1.4 \%$ & $18.2 \%$ \\
\hline \multirow[t]{2}{*}{ Plecoptera } & 700 & 113 & 8 & 32 & 5 & 880 & 85.5 \\
\hline & $6.9 \%$ & $1.6 \%$ & $0.0 \%$ & $0.0 \%$ & $2.1 \%$ & $5.5 \%$ & $0.5 \%$ \\
\hline \multirow[t]{2}{*}{ Odonata } & 7 & $\mathbf{0}$ & $\mathbf{0}$ & $\mathbf{0}$ & $\mathbf{0}$ & $\mathbf{0}$ & 8 \\
\hline & $0.1 \%$ & $0.0 \%$ & $0.0 \%$ & $0.0 \%$ & $0.0 \%$ & $0.0 \%$ & $0.0 \%$ \\
\hline \multirow[t]{2}{*}{ Trichoptera } & 2267 & 2160 & 4968 & 3448 & 40 & 5 & 2447.5 \\
\hline & $22.4 \%$ & $31.6 \%$ & $4.6 \%$ & $4.0 \%$ & $16.7 \%$ & $0.0 \%$ & $13.3 \%$ \\
\hline \multirow[t]{2}{*}{ Coleoptera } & 1227 & 190 & 2160 & 2800 & 10 & 80 & 1779.5 \\
\hline & $12.1 \%$ & $2.8 \%$ & $2.0 \%$ & $3.3 \%$ & $4.2 \%$ & $0.5 \%$ & $9.7 \%$ \\
\hline \multirow[t]{2}{*}{ Chironomidae } & 3473 & 2827 & 31168 & 48696 & 125 & 8115 & 8392 \\
\hline & $34.4 \%$ & $41.4 \%$ & $28.7 \%$ & $56.9 \%$ & $52.1 \%$ & $50.5 \%$ & $45.7 \%$ \\
\hline \multirow[t]{2}{*}{ Other Diptera } & 93 & 843 & 6680 & 5280 & 0 & 150 & 134.5 \\
\hline & $0.9 \%$ & $12.3 \%$ & $6.1 \%$ & $6.2 \%$ & $0.0 \%$ & $0.9 \%$ & $0.7 \%$ \\
\hline \multirow[t]{2}{*}{ Oligochaeta } & 13 & 47 & 2512 & 400 & 5 & 6485 & $\mathbf{5 7 5 . 5}$ \\
\hline & $0.1 \%$ & $0.7 \%$ & $2.3 \%$ & $0.5 \%$ & $2.1 \%$ & $40.4 \%$ & $3.1 \%$ \\
\hline \multirow[t]{2}{*}{ Mollusca } & 33 & 7 & 43408 & 8848 & 25 & 75 & 644 \\
\hline & $0.3 \%$ & $0.1 \%$ & $39.9 \%$ & $10.3 \%$ & $10.4 \%$ & $0.5 \%$ & $3.5 \%$ \\
\hline \multirow[t]{2}{*}{ Others } & 1300 & 430 & 7232 & 6152 & 25 & $\mathbf{5 0}$ & 963 \\
\hline & $12.9 \%$ & $6.3 \%$ & $6.7 \%$ & $7.2 \%$ & $10.4 \%$ & $0.3 \%$ & $5.2 \%$ \\
\hline TOTAL & 10110 & 6833 & 108648 & 85608 & 240 & 16070 & 18360 \\
\hline TOTAL TAXA & 30 & 30 & 42 & 42 & 17 & 34 & 62 \\
\hline EPT & 13 & 12 & 10 & 9 & 3 & 8 & 23 \\
\hline
\end{tabular}




\section{DISCUSSION}

According to Poff \& Ward (1989), the predictability of flow regimes determines whether the biotic or the abiotic factors are the ones that control the structure of communities. Very variable and/or unpredictable flow regimes generate a physical environment in which abiotic processes determine community organization, while a more predictable regime encourages interactions among the biota, such as competition or predation, factors which will control the community structure (Gasith \& Resh, 1999). The Matarranya is a Mediterranean stream and, given its type of hydrological regime, the time of year when most floods will appear can be predicted, but their frequency and/or intensity cannot. This pattern can present itself among rivers with an unpredictable flow regime in general terms, for which Poff and Ward (1989) established that the communities are regulated by abiotic factors, more specifically by the frequency and predictability of the floods that determine a community composed of species with mechanisms capable of avoiding this type of perturbation (Puig et al., 1991). Previous studies of the biota in this river demonstrated that certain species had adapted their life cycle to avoid floods (Pupilli \& Puig, 2002), for example the bivoltine cycle of Perla marginata (Puig, 1993), Hydroptila insubrica o Hydropsyche instabilis (Recasens \& Puig, 1987). In general terms, it has been observed that passage from the typical summer community in this river to that of autumn-winter is marked by the beginning of the autumn floods. A similar situation regarding species adaptation has been observed in the Ter basin (Puig et al., 1990) and in other Mediterranean basins (Puig et al., 1986).

Typical winter communities for the sampling stations at Parrissal and Vall-de-roures differed both in specific composition (only 21 of the 112 species found in both places coinciding) and richness (42 taxa in Vall-de-roures-de-roures compared with the 56.5 of Parrissal). The mean density of macroinvertebrates in Parrissal for winter months before the flood was 14760 indi- viduals $/ \mathrm{m}^{2}$, while in Vall-de-roures it was 97128 individuals $/ \mathrm{m}^{2}$. The differences in structure and density of the communities reflect the usual differences in pollution/eutrophication found in Mediterranean rivers (Sabater et al., 1995), although cushioned in this case by the dilution of nutrients caused by the increased summer flow in Vall-de-roures due to regulation of the river (Ward \& Standford, 1983)

The effect of the flood in 2000 on macroinvertebrate densities was similar in both stations, the number of individuals falling by $97.6 \%$ in Parrissal and $99.7 \%$ in Vall-de-roures. Similar reductions in the overall densities of macroinvertebrate communities have been recorded in La Rambla del Moro after the 1982 flood (Ortega et al., 1991) and in other Mediterranean rivers (Fenoglio et al., 2001). The number of taxa present after the flood in Parrissal was $31.9 \%$ of the previous number, while the corresponding figure in Vall-de-roures was $40.5 \%$, similar to the losses caused by the catastrophic flood of 1983 in the Ter River (Puig et al., 1987; Sabater et al., 1995). After the flood in 2000, the groups representing more than $75 \%$ of the community in Parrissal were the mayflies, stoneflies, beetles, and chironomids, while the predominant groups in Vall-de-roures were the chironomids, caddisflies, and freshwater snails.

The pace of the recovery differed between the two stations. In March 2001 the density in Parrissal was $37.9 \%$ of the pre-flood community, while in Vall-de-roures it was $14.79 \%$. In January of 2002 the corresponding percentages were $80.2 \%$ in Parrissal and $21.47 \%$ in Vall-deroures. The recovery of the taxonomic richness also differed between the two stations since in Parrissal, fifteen months after the flood, the total number of taxa was 57 as opposed to the mean number of 56.5 recorded before the flood, the corresponding numbers in Vall-de-roures being 62 fifteen months after and 42 before. There was also a proportionally greater increase in Vall-de-roures of species that were intolerant of pollution, as reflected by the EPT index. This increase in taxonomic richness was also registered in the Ter River in polluted stations such as 
those lying between Ripoll and the entrance of the river Gurri (Puig et al., 1987).

The effect of the less important floods studied in both stations (October 1984 in Parrissal and June 1986 in Vall-de-roures) followed a similar pattern, with substantial initial losses in population densities but with most of the taxa composing each remaining community. At the same time, the macroinvertebrate community in Parrissal remained stable, while that in Vall-deroures underwent a certain degree of disorganization. A comparison of these effects with those resulting from the 2000 flood, points to certain differences and their relatively small magnitude. The macroinvertebrates of communities subjected to fluctuating flows show a high degree of resistance to moderate flooding (Resh et al., 1988; Puig et al., 1991; Fenoglio et al., 2001), and need little time to recover. An example of such resilience was observed in the Ter basin, where recovery took six to nine months, depending on the station in question (Puig, 1987; Sabater et al., 1995). However, the Matarranya River took longer to recover after the catastrophic flood of 2000, up to 15 months in the case of community structure, though with a high level of species change. Regarding the apparently long time it took for the densities to recover in Vall-de-roures, if the fact that the pollution levels fell to values similar to those of 1986 is taken into account, it may be said that this station recovered fully, showing a similar behavioral pattern to the Parrissal station. The reason for the differences observed between the recovery of the Ter and Matarranya communities is almost certainly due to the magnitude of the flood suffered by the Matarranaya River.

\section{REFERENCES}

FENOGLIO, S., M. BATTEGAZZORE. \& A. MORISI. 2003. Alluvioni e comunità macrobentoniche: una panoramica complessiva ed alcuni casi di studio in Piemonte. Pianura, 17: 199-206.

GARCÍA-RUIZ, J. M., J. PUIGDEFÁBREGAS \& J. CREUS. 1985. Los recursos hídricos superficiales del Alto Aragón. Colección de estudios arago- neses 2, 1st ed. Huesca: Instituto de Estudios Altoaragoneses

GASITH, A. \& V. H. RESH. 1999. Streams in Mediterranean climate regions: Abiotic influences and biotic responses to predictable seasonal events. Annual Reviews: Ecology and Systematics, 30: 51-81.

GIBBINS, C. N., C. F. DILKS, R. MALCOLM, C. SOULSBY \& S. JUGGINS. 2001. Invertebrate communities and hydrological variation in Cairngorm mountain streams. Hydrobiologia, 462: 205-219.

LENAT, D. R. 1988. Water quality assessment of streams using a qualitative collection method for benthic macroinvertebrates. Journal of North American Benthologic Society, 7 (3): 222-233.

MALO, J. 1993. Comunidades bentónicas de rios mediterraneos. Ph. D. Thesis, Universidad de Murcia. $200 \mathrm{pp}$.

O. D. P. M., Office of Deputy Prime Minister. 2002. Methods for data analysis of benthic samples. In: Guidelines for the conduct of benthic studies at aggregate dredging sites. 77-86, Centre for Environment, Fisheries and Aquaculture Science \& Department for Transport, Local Government and the Regions, UK

ORTEGA, M., M L. SUÁREZ, M. R. VIDALABARCA \& L. RAMÍREZ-DÍAZ. 1991. Aspectos dinámicos de la composición y estructura de la comunidad de invertebrados acuáticos de la Rambla del Moro después de una riada (Cuenca del río Segura: SE de España). Limnetica, 7: 1124.

POFF, N. L. \& J. V. WARD. 1989. Implications of streamflow variability and predictability for lotic community structure: A regional analysis of streamflow patterns. Can. J. Fish. Aquat. Sci., 46: 1805-1817.

POFF, N. L. 1996. A hydrogeography of unregulated streams in the United States and an examination of scale-dependence in some hydrological descriptors. Freshwat. Biol., 36: 71-91.

PRAT, N., G. GONZÁLEZ, X. MILLET \& M. A. PUIG. 1985. El Foix entre l'eixutesa i la contaminació. Monografies. Diputació de Barcelona, Servei de Medi Ambient. Barcelona. 95 pp.

PUIG, M. A., M. FERRERAS-ROMERO \& A. M. G. ROJAS. 1986. Ecosistemas de ríos temporales: ecología de las poblaciones de efemerópteros de la cuenca del río Bembézar (Sierra Morena). Anales de Biología, 8: 65-69. 
PUIG, M. A., G. GONZALEZ \& L. RECASENS. 1987. Modelos de distribución de plecópteros, efemerópteros, tricópteros y simúlidos en el río Ter. Limnetica, 3: 125-132.

PUIG, M. A., F. SABATER \& J. MALO. 1990. Benthic and hyporheic faunas of mayflies and stoneflies in the Ter river basin (NE-Spain). In: Mayflies and Stoneflies. 255-258. Kluwer Academic Publishers, Dordrecht.

PUIG, M. A., M. ABOAL \& A. DE SOSTOA. 1991. New approaches to Mediterranean fluvial communities. Oecologia Aquatica, 10: 13-20.

PUIG, M. A. 1993. Relaciones tróficas de la comunidad de macroinvertebrados en el río Matarraña (cuenca del Ebro). Actas VI Congreso Español de Limnología. Granada., España: 355-362.

PUPILLI, E. \& M. A. PUIG. 2003. Effects of major flood on the mayfly and stonefly populations in a Mediterranean stream (Matarranya Stream, Ebro River Basin, North East of Spain). In Research update on Ephemeroptera \& Plecoptera. 381-389. Gaino E. (ed). Università di Perugia. Perugia, Italy.

RECASENS, L. \& M. A. PUIG. 1987. Life cycles and growth patterns of Trichoptera in the Matarraña, a karstic river. In: Proceedings of the 5th International Symposium on Trichoptera. M.
Bournaud \& H. Tachet (eds.): 247-251. Dr. W. Junk Publishers, Dordrecht, The Netherlands.

RESH, V. H., A. V. BROWN, A. P. COVICH, M. E. GURTZ, H. W. LI, W. MINSHALL, S. R. REICE, A. L. SHELDON, J. B. WALLACE \& R. C. WISSMAR. 1988. The role of disturbance in stream ecology. J. N. Am. Benthol. Soc., 7 (4): 433-455.

SABATER, F., H. GUASH, E. MARTÍ, J. ARMENGOL. \& S. SABATER. 1995. The Ter: a Mediterranean river case-study in Spain. In: River and stream ecosystems. Ecosysytems of the world 22. C. E. Cushing, K. W. Cummins \& G. W. Minshall (eds): 419-438. Elsevier Science B.V., Amsterdam.

THOMSON, J. R. 2002. The effects of hydrological disturbance on the densities of macroinvertebrate predators and their prey in a coastal stream. Fresh. Biol., 47: 1333-1351.

WARD, J. V. \& J. A. STANDFORD. 1983. The intermediate-disturbance hypothesis: an explanation for biotic diversity patterns in lotic ecosystems. In: Dynamics of Lotic Ecosystems. J. V. ward and J. A. Standard (eds): 347-356. Ann Arbor Science Publishers, Michigan.

WOODWARD, G., J. I. JONES. \& A. G. HILDREW. 2002. Community persistence in Broadstone Stream (U.K.) over three decades. Fresh. Biol., 47: 1419-1435. 